\title{
ZGORNJA GOZDNA MEJA SLOVENSKIH ALP, VISOKIH KRAŠKIH PLANOT IN PROKLETIJ
}

\author{
Franc Lovrenčak: Zgornja gozdna meja slovenskih Alp, visokih kraških planot in \\ Prokletij. Razprave Filozofske fakultete, 217 str. Znanstvenoraziskovalni inštitut \\ Filozofske fakultete, Ljubljana 2007.
}

Meje so namenjene razmejevanju. Najpogosteje kot pas ali prehodno območje, redko kot ostro zarezana črta. Vendar je kljub vsemu na eni strani nekaj, na drugi strani nekaj drugega. Včasih je sila pomembno, na kateri strani meje si. Stvari se ob prehodu meje lahko bistveno spremenijo. Meja včasih postane črta med življenjem in smrtjo. Kot že ime pove, je zgornja gozdna meja tudi meja. Gre za zelo izrazito in očitno mejo. In prav pri tej meji gre za življenje ali smrt. Višje od nje gozd ne more več uspevati. Pa tudi samo mejo lahko dosežejo le najvztrajnejši in najbolj odporni. Niti ne največji, niti ne najbolj košati. Ampak najpogumnejši. Gre za drevesne vrste, ki morejo kljubovati najbolj surovim vremenskim in reliefnim pogojem. Podnebje je skoraj polarno. Zelo kratka vegetacijska doba, omejena le na nekaj poletnih mesecev. Ekstremne količine padavin v pretežni meri padejo kot sneg, ki obleži in ugodno rastno obdobje še skrajšuje. Vetrovi so izjemno močni. Lomijo veje in skupaj z ledenimi kristali oblikujejo vetrovne krošnje. Izrazita temperaturna nihanja, tako prek leta, kot tudi prek dneva. Sončno obsevanje je intenzivno, z nadpovprečnim deležem za kambij smrtonosnim UV žarčenjem. Prsti skorajda ni. Malenkostno mehansko preperela trda matična podlaga, s surovim, kislim in nehranilnim, prhninastim humusom. Visoki nakloni in obilica padavin preko erozijskih procesov stalno tanjšajo prsti in jih ohranjajo na mladi razvojni stopnji. Kljub obilici padavin voda po strmem reliefu hitro odteka po pobočju, zato je primanjkuje in suša je pogost pojav. Ne smemo pozabiti še na snežne plazove, ki stalno udarjajo prav v prve vrste dreves. Predvsem v preteklosti je v mejo posegal tudi človek, ko je skušal pridobiti primerne površine za pašo živine.

Na zgornji gozdni meji se drevesa znižajo, zaradi pomanjkanja vode in hranil se veča razdalja med posameznimi primerki in strnjen sestoj razpade na manjše skupine ali posamezna drevesa. Debla dreves so upognjena, veje se razvijejo le na eni strani in so zvite, vrhovi odlomljeni. Višje uspeva sklenjeno le še ruševje, vmes se pojavljajo jerebika, nekatere vrbe ter pritlikavi, oleseneli in blazinasti grmički dlakavega sleča in navadnega slečnika.

V Sloveniji se zgornja gozdna meja pojavlja v Alpah ter na visokih kraških planotah Snežnika in Trnovskega gozda. V Julijskih Alpah se pojavlja klimatska, termična gozdna meja in prav v najbolj masivnem in najvišjem osrednjem delu sega najvišje, do $1900 \mathrm{~m}$ nad morjem. Drugod je nižja in se spusti vse do 1600 m. Kamniško-Savinjske Alpe, ki so nižje in bolj razčlenjene, zaznamuje nižje ležeča gozdna meja, ki ne preseže $1800 \mathrm{~m}$, spusti pa se tudi pod mejo $1600 \mathrm{~m}$. V Karavankah se gozdna meja zopet dvigne ter na pobočjih Pece doseže skoraj $2000 \mathrm{~m}$. Zgornjo gozdno mejo tvorita predvsem smreka in na prisojnih pobočjih macesen. Zgornja gozdna meja visokih kraških planot je nižja, vendar ne le zaradi nadmorske višine, marveč tudi zaradi povsem drugačnih rastiščnih razmer in delovanja človeka. Meja poteka na višinah od 1450 do $1550 \mathrm{~m}$ in jo tvori v glavnem bukev. 
Monografsko delo Zgornja gozdna meja slovenskih Alp, visokih kraških planot in Prokletij Franca Lovrenčaka predstavlja dejansko njegov Opus magnum. Gre za tematiko, ki si jo je avtor izbral že za svojo doktorsko disertacijo in ji je tudi posvetil glavnino plodnega raziskovalnega časa. Je tudi rezultat mnogoletnih preučevanj, ki jih je avtor objavljal v različnih publikacijah in predstavil na številnih domačih in tujih zborovanjih ter kongresih. Prav v tej razpršenosti objav tiči razlog, čemu se je avtor odločil, da na enem mestu zbere celotno napisano gradivo, da bo na voljo tistim, ki jih ta problematika zanima. Prispevki v monografiji so urejeni po kronološkem vrstnem redu ter $\mathrm{v}$ obliki in jeziku, $\mathrm{v}$ katerem so bili prvotno objavljeni (nekateri prispevki so v angleškem in srbohrvaškem jeziku).

V najstarejših prispevkih iz začetka osemdesetih let govori Franc Lovrenčak o zgornji gozdni meji po Jugoslaviji, predvsem v Julijskih Alpah in črnogorskih Prokletijah. Kasneje se povsem osredotoči na razmere v Sloveniji in večji del monografije nameni geografskemu vidiku zgornje gozdne meje v slovenskih Alpah in na visokih kraških planotah. Podrobno predstavi vse naravne razmere, ki se pojavljajo na preučevanem območju in vplivajo na samo zgornjo gozdno mejo, še poseben poudarek je namenjen prstem in vrstni sestavi gozda. Natančno in dosledno lahko bralec spozna, kje je v tistem času potekala zgornja gozdna meja ter kaj pogojuje njen potek.

Zadnje sintezno poglavje opredeli osnove tipe zgornje gozdne meje v Sloveniji, najprej naravno (namišljeno, abstraktno) in antropogeno, umetno (dejansko, konkretno) ustvarjeno gozdno mejo. Naravna meja se še naprej deli na orografsko, plazovno in klimatsko. Orografsko ali reliefno gozdno mejo opredeljuje naklon, saj se gozd zaključi neposredno pod stenami in ob meliščih. Plazovno gozdno mejo nekateri opredeljujejo kot podtip orografske in jo določa spodnja meja, do koder še vplivajo snežni premiki. Tretji, klimatski tip zgornje gozdne meje, ima dva podtipa: termičnega, ki ga opredeljujejo temperature v vegetacijski dobi, in vetrovnega, ki se uveljavlja na grebenih. Nič manj pomembna ni antropogena ali dejanska gozdna meja, ki poteka nižje, kot če vpliva človeka ne bi bilo, in je posledica krčenja gozda za pridobivanje pašnih površin.

Meje danes skušamo v glavnem odpraviti, saj nas omejujejo. Vendar nekaterih ne moremo. So tako izrazite in očitne. Nekatere meje nam predstavljajo izziv, da jih presežemo, premikamo višje ali dlje oziroma jih želimo čim bolje spoznati. Zgornje gozdne meje Franc Lovrenčak ni želel nikdar preseči ali premakniti, pa vendar mu je predstavljala življenjski izziv, ki ga je pogumno sprejel, osvojil in presegel. In najlepše je to vidno prav v predstavljeni monografiji.

V razmerah na zgornji gozdni meji lahko uspevajo najodpornejši. Pionirske vrste. Tiste, ki prve naselijo ogolele površine in ustvarijo primerne razmere za rast drugih, zahtevnejših rastlin $\mathrm{z}$ večjimi potrebami. Tudi v primeru gozdne meje zadržujejo vodo, s koreninami stabilizirajo pobočja in melišča, prispevajo za prst prvo organsko gradivo in varujejo podmladek ter nižje ležeče sestoje pred snežnimi plazovi. Med ljudmi takšne osebe označujemo kot pionirje, ki prvi ali med prvimi pridejo $\mathrm{v}$ do takrat še ne poznane, ne zavzete kraje, osvajalce ali tudi prvi začnejo delovati, ustvarjati na novem, neznanem področju znanosti. Tudi pobudniki in začetniki. Vse to je Franc Lovrenčak v slovenski geografiji nedvomno bil in je. Bil je prvi, ki je utemeljil geografijo prsti in rastlinstva ter ju enakovredno postavil ob bok ostalim vejam geografije. Kljub temu da so pred njim gozdno mejo preučevali Anton Melik, Ivan Gams 
in Danilo Furlan, se je Franc Lovrenčak tega lotil temeljito in sistematično, zato na tem področju njegovemu delu še danes ni enakega. Kot pravi pionir je pripravljal teren ter utiral in tlakoval naporno pot, da bo tistim, ki mu sledijo, lažje. Kot avtor tega skromnega prispevka moram zato na koncu dodati še: veliko lažje mi je hoditi in mi je obenem v neizmerno čast. Profesor Lovrenčak, hvala!

Blaž Repe 